\title{
Regulation of special legal order in Hungary \\ - Constitutional options in the shadow of the COVID crisis
}

\author{
Dr. István SIMICSKÓ
}

\begin{abstract}
States often try to find a way of dealing with social problems and crises by legal institutions. The regulations of special legal order occupy a unique place among the general constitutional rules of the Hungarian legal order. The need of introducing special legal order means that Hungary is in a situation which requires special legal instruments from the state in order to return to the normal operation of the country determined by the normal legal order as soon as possible. The fact that the freely elected legislative power, the National Assembly determines the content and form of the cases when a deviation becomes possible from the general rules is an important pillar of the stability of the democratic state. Based on the principle of proportionality, there are different types of special legal order, consequently the concentration of power is possible only when it is absolute necessary to deal with the situation. Finding the balance between efficiency and the risk of abuse is very important. So special legal order is always temporary and ultimate, which can be applied as an ultima ratio of the legislation in the times of need, but only if their every constitutional conditions are met. Potential threats change constantly, so the regulations of special legal order also need to be updated from time to time.
\end{abstract}

\section{Keywords}

special legal order, qualified period

\section{Constitutional regulation of special legal order in the 20th century}

\section{The development of special regulations until the end of the Great War}

The Compromise Act finally concluded and enacted in 1867 regulated the relations between Hungary and Austria and at the same time introduced an extraordinary period in the historical development of Hungarian constitution, enabling the Hungarian Assembly to initiate decisions as a legislative body in the majority of cases relating to the security of the country. The intense need of the economy for natural resources led to the interest 
in territorial expansion and in colonization. Following the national awakening movement of the 19th century the claim of establishing national states appeared in a fever of excitement. At the rise of the 20th century the foreign policy of the great world powers could be best characterized by the term imperialistic. Without further thorough investigation one safely may come to the conclusion that these factors already enclosed the conflicts appearing between these countries, gravely endangering the status quo of that time. In this new era of the changes of military devices and military aims characteristic over the centuries as well as the influence of mass communication the Hungarian legislative body - adapting itself strictly to the framework of the Austro-Hungarian Monarchy - had to recognize the necessity of the formation of a legislation applicable in any extraordinary situation, in the interest of efficient action.

In 1912, after the outbreak of the 1. Balkan War legal acts previously unknown in Hungarian legislation were drawn up to establish the special rules and regulations concerning the conduct of total war. Apart from expanding the army the overall plan of mobilization and economical mobilization were designed, as well as the legal framework of practical measures which facilitated the war effort, e. g. supplementing judicial process and possible penalties, introducing restrictions on freedom of the press, the right of association, the right of assembly and of other civil rights. The first step is represented by the Act XXXI. of 1912, concerning the army. After a short period of preparatory work the Act LXIII. of 1912 of special measures in the time of war, had gone through Parliament. In the framework of the present legislation this Act has created a legal institution similar to the state of emergency that is the state of war. The Act LXIII. of 1912 states: „In the times of war, moreover, if necessary already in the period of military preparations ordered in the circumstances of a threat of war the Ministry of War taking on full personal responsibility applies exceptional power to the extent appropriate in the given situation... When war is over the exceptional power will terminate. The extraordinary measures implemented during the course of extraordinary power are to be overruled unless the Parliament supports to further maintain them. ${ }^{1}$ In sum, the Parliament established the possibility of furnishing the government with additional rights to manage these circumstances - meaning war-threat at that time -, assigning at the same time a temporal limit to the extraordinary authorization bestowed upon the government. The decision concerning the extension of the decisional authority was assigned to the hands of the supreme legislative body, the Parliament. Furthermore, in order to assure public opinion, the temporary nature of the curtailments of the general human rights was secured in several articles.

In 1914 the number of qualified temporary laws pertaining to war were increasing. This legislation assessed further restrictions on official tariff rates, on stacking and release of means of sustenance; further strict criminal sanctions were decided in cases against the interest of home-defence; new legislation controlled the reallocation of firms and of all forms of productive activity into war-time economy and the introduction of labour of public utility, the legal frame for implementing these extraordinary measures by the use of enforcement, general public sanitary rules, as well as the control of media, the activity of unions and associations, and the restrictions of general freedom rights were legally determined. ${ }^{2}$

1 Act LXIII. of 1912 on the extraordinary measures in the event of war, paragraph 1.

2 Act LXIII. of 1912 on the extraordinary measures in the event of war, and the 1. amendment of 1914 to the Act LXVIII. of 1912 on the provision of war services. 
The Constitution of the Republic of Councils in Hungary declared on 23 June 1919 presented a short intermezzo in the historical Constitutional development of Hungary. The Constitution of the Socialist Allied Council Republic of Hungary was in fact the first charter-like constitution in Hungarian history. According to this constitution as general rule the Revolutionary Governing Council disposed of all executive power in the Hungarian Soviet Republic and governed the country by issuing decrees without any democratic guarantees. Thus, it seems perfectly natural that this legal document did not contain rules or articles concerning special legal order.

In these turbulent times after the Great War people had to experience and survive a crisis reminding us of the Corona virus pandemic of 2020. One century earlier the Spanish flu, also known as the 1918 influenza pandemic caused the death of 50 million people. The Spanish flu was the first appearance of the influenza A virus, spreading and killing people very fast. The virus also killed people directly by destroying the healthy tissues and causing massive haemorrhages in the lungs. In Hungary nearly 50 thousand people died of the Spanish flu. Great personalities of the nation, the last king of Hungary Charles IV, the poet Endre Ady, the painter Tivadar Csontváry Kosztka, the scientist Loránd Eötvös, the novelist and poetess Margit Kaffka fell victim to the pandemic. At that time due to the lack of organized disinfection of the streets and other public spaces the spread of the pandemic had not been controlled or detained. The co-operation of states in sanitary defence policy had been missing, and there had not been enough working force or equipment to control and maintain the grave situation in adequate measures. ${ }^{3}$ The hereby mentioned tasks are what one could call acts for common good that require state resources and the executive power. Although several restrictions (quarantine, censorship) had been introduced to a different degree of effectiveness, without the relevant framework of rules the special legal order could not been introduced.

\section{On the road to the Second World War}

In the first three decades of the 20th century the development of sciences especially that of military science and military technology witnessed an unprecedented speed and intensity. The appearance of the new types of weapons gave a motivation to developing the adequate answer, the effective device of counter-move. Chemical weapons and bombs dropped from aeroplanes seemed the most perilous with regards to both civilians and soldiers. From then on the home front, including big cities, industrial centres, important points of public transport, as well as the centres of state administration and military command could be reached and attacked fast and relatively easily. It had become necessary therefore to devise the new theory and the new method of defence with a renewed legal and institutional system. The Act XII of 1935 seems to be the perfect example of this effort in Hungary. The article declares that "Every Hungarian citizen between 14 and 60 - regardless their sex - is obliged to participate - according to their physical capability - in air-raid precautions and civil defence air-raids, prior to participation these persons are obliged to take part in the course of proper training. In the interest of defence (...) during the time of need

3 Németh Hajnalka: Spanyolnátha. A világméretű rejtélyes járványról egy kicsit másképp. In: Better Responsibility Initiative, 2019-2020. (Spanish Flu. Reflections on the Mysterious Pandemia from a Different Viewpoint). 
the necessary measures may be adopted to confine the freedom of movement and citizens must oblige these special orders, with extraordinary measures, if necessary. ${ }^{\prime \prime 4}$ The above mentioned orders created the possibility of introducing the confinement of constitutional rights, in response to a challenging situation.

With regard to temporary legal measures the terminology applied currently in the state of emergency or special powers had been created in the 1930s. The complexity of national defence (the defence of the country) is amply demonstrated by the commonly accepted view of the necessity of preparing the country's economy for the introduction of war economy at the same time ensuring qualified temporary provisions for the citizens. The second article of the Act II of 1939 became the first example in Hungarian legal history which employed the results of Legal science, military science, economics, the science of organization and psychology. The qualified period is mentioned as "special power" and its regulations are discussed in detail. The government is enabled to introduce "special power" and the necessary measures and arrangements are enacted by decree. "In the period of war or military abuse threatening the country the ministry - each member taking personal responsibility - may ordain the specified orders (extraordinary power) in accordance with the measures of need and until further decision of the Parliament (...) The exact day of the establishment of the possibility of exercising special power is to be announced in public by the ministry. ${ }^{15}$

\section{Period of lost independence}

From the German occupation of the country on 19 March 1944 until the year of 1948 the sovereignty of Hungary ceased to exist. Right after the war, he first period of socialism in Hungary was characterized by open dictatorship. We have reason to ascertain that the methodology of power-exercising was best defined by the term "state of emergency", even if there were longer periods when special regulations restraining everyday private life (curfew, evacuation) were not in force. The 1956 Hungarian revolution and freedom fight differed from the previous decade inasmuch as the state of emergency as defined by legal terminology changed into "extraordinary period". The Act XX of 1949 on the Constitution of the Hungarian Peoples' Republic was designed by the pattern of the Stalinist Soviet Constitution. It contained no examples of special legal order cases, while the Act of National Defence in 1960 has a whole section dealing with extraordinary regulations. ${ }^{6}$ This law reveals the real relation of the political power to democracy: the censorship, the limitation of the right of assembly are missing from the list of extraordinary regulations as they had been well in force in the time of peace. The logic of this system is well characterized by the words of András Jakab and Szabolcs Till: the special legal order can only be interpreted in a constitutional state, in the rule of law. In the case where the state exercises unrestricted power without the guarantees against abuse, further authorization seems unnecessary. ${ }^{7}$

4 Act XII. of 1935, , on air defence system, paragraphs 1 and 2.

5 Act XX. of 1938 on military defence, on the development of economy, on welfare developments and their financial background

6 Act IV. of 1960 on national defence.

7 Jakab András - Till Szabolcs: X. Alkotmányvédelem - Különleges jogrend, JAK - PPKE, 1033-1072. 


\section{From the end of Socialism to the present day}

During the years previous to and immediately following the "regime change" the formation of the framework of the rule of law which presents a milestone in the constitutional conditions of special legal order. The Act XXXI of1989 on the amendment to the Constitution - put into force on 23 October 1989 - modified the Act XX. of 1949 and thus became the Constitution of the Hungarian Republic containing articles to eliminate the party state structure, to introduce democratic proportions as well as the basic constitutional rules concerning the extraordinary order and state of emergency. The enactment of the first two instances was placed in the authority of the Parliament as an actor of popular sovereignty in order to assure the constitutional order of the society. "in the danger of hostilities or military assault by a foreign power the Parliament announces extraordinary order and establishes a Council of Defence; the Parliament declares a state of emergency in the cases of armed attacks to seize political power, outbreaks of armed violence against lives or properties of citizens and in times of natural disaster or industrial catastrophe (in the following: emergency). ${ }^{\prime 8}$ The third instance, the emergency condition was placed in the competence of the government (then called the Ministerial Council): "in the cases of natural disasters threatening the security of human life and the property of citizens, in order to solve the consequences in the interest of the protection of public order and public condition, in other words it is the Parliament who decides on the extension and further maintaining of the special legal order. Each of the three cases grants central role to the government, as in the case of the state of war the previously rather important body, the Council of National Defence no longer exists, as for the case of the state of emergency the wider authority of the president of safety" 9 the government is authorised to take the necessary measures including the establishment of regulations different from the provisions of laws, in possession of the authorisation of the Parliament. It was the wish of the legislator to make arrangements for the specific details in an individual law with constitutional force. Defence is declared a national issue by theAct CX. of 1993 on defence, referring to the relevant passages of the Constitution this law contains the rules to be applied in extraordinary order and emergency condition, as well as the establishment of the Council of Defence. The legislature also notes the citizens' obligation to partake in civilian defence and the obligation of sharing information considered commercial secrecy during qualified period. A whole chapter is dedicated to the detailed rules applied in extraordinary order and state emergency, whereby the powers conferred to the president of the republic, to the Council of Defence and to the government who were authorised to introduce serious restrictions of constitutional rights with the use of a wide range of instruments. Among them we could mention the ante-check of other communications that might serve the media or any sources of communication and their publication with permission, the limitation of the use of certain routes of traffic (on roads, on water and in air) to certain areas or the total withdrawing of traffic, the introduction of curfew for citizens, binding public events or any other assembly in a public place to previous permission, the relocation

8 The Act XX. of 1949, paragraph 19, subparagraph (3), points h) and i). (status of 23. 10. 1989).

9 The Act XX. of 1949, paragraph 35, subparagraph (1), point i), (status of 23. 10. 1989). 
of citizens from a specific territory for a limited period of time, the limitation of travelling either of Hungarian citizens to another country or foreign citizens to Hungary, the ordering of continued civilian defence service.

Compared to the previous legislation the introduction of the case of unexpected attacks based on the experience of the Balkan War-in 1994 and the modification of the Constitution in 2004 demonstrated a most important change whereby the case of preventive defence as a qualified period has been introduced which can be declared "in the danger of foreign military attack or in order to meet the obligation to our allies for a determined period."10 The political change, or "change of regime" was taking place in a world built on the possible confrontation between the East and the West, in an atmosphere just about to recover from the cold war. Therefore, the old fixations in security policy played relevant role in the process. After some time, with the intention of stoking the furnace which was supposed to incorporate the whole world increasingly gained ground, respective Hungarian governments had to face quite different security challenges. In 1989 these changes - experienced today as sad reality - existed only in the form of dystopian predictions. The legislation of the special order of rights of that time was characterised more by the spirit of protecting the major new democratic achievement than by the pursuit of providing flexible reaction to the then unseen social and economy changes. Árpád Farkas recalls Professor István Kukorelli's memories of the so-called "round table negotiations" of the opposition and notes that the main goal of the "regime change" seems to have been to force the apparatus of the armed violence of the state in the parliamentary framework of the separation of power, diminishing the effectiveness of operation, if necessary. ${ }^{11}$ Later, parallel to the recognition and spread of the dangers of hybrid warfare, terrorism, and cyber-attacks the legislative body made serious effort to synchronize the regulations with the modern challenges thinking that the special regulation concerning a certain type of cases may be more effective, bearing in mind - as we see later - the sceptre of possible threats is wider and more diverse therefore it was not possible to create a separate characterization of facts of qualified periods. In the study of the problem of hybrid warfare one may conclude that as this is not the case of a declared war therefore it is impossible to seek combat against it in the traditional way of the use of armed forces, only with conducting adequate, indirect countermeasures. ${ }^{12}$ The special legal rules brought into force in the interest of security thus form a part of this indirect defence.

Bearing in mind the lesson taught by the 20th century, and at the same time following the example of western European democracy special attention had to be paid in the given qualified situation that - in order to protect or acquire security - the measure of restriction should be in accordance with the measure of the threat and danger. For the effectiveness of protection it is important to ensure that citizens realize what the real and actual danger

10 Simicskó István: A terrorizmus elleni védelem fokozása a különleges jogrendi kategóriák bővítésével, In: Hadtudomány 2016/3-4. 113. (The enhancement of defence against terrorism with increasing the categories of special legal order.

11 Farkas Ádám, Az állam fegyveres védelmi rendszerének kérdései a kortárs fenyegetések tükrében, Katonai Jogi és Hadijogi Szemle 2015/1, 140-142. (The questions of the state armed defence system in the in the reflection of contemporary threats).

12 Simicskó István: A hibrid hadviselés előzményei és aktualitásai, Hadtudomány, 2017/3-4. (The precedents of hybrid warfare and its actualities). 
or security is. It is hazardous irresponsibility if the sense of security of the society is kept lowkey, on the other hand the normal functioning of any society could be pushed over if people are constantly warned of some lurking disaster by overprotection of special regulations upsetting the rhythm of everyday life..$^{13}$ In the rule of law the sense of security of a society is to a great extent supported not only by the appropriate condition of armed forces and other forces of security but also by the stability of the legal system and the unanimity of legal regulations. It is necessary to record that the discretion of the state cannot be limitless or unrestricted, not even in the state of special legal order. ${ }^{14}$ It is the duty of the state to safeguard security for its citizens and to provide adequate circumstances for living in security. The actual government is evaluated by its approach to the problem of security and the measure the government is able to provide protection to its citizens.

\section{The Establishment of the existing regulation}

\section{The rules of special legal order in the Fundamental Law of Hungary}

The Fundamental Law entering into force on 1 January 2012 opened a new chapter in the development of the Hungarian constitution, it also introduced the terminology of special legal order and adapted the essential basic legislative terminology concerning the qualified periods from the previous legislation. In the reasoning attached to the Fundamental Law the legislative body stated that the principles of the classical constitutional state can be suspended or limited in the special legal order stating at the same time that any derogation from the principles of democracy or from the rules codified in the Fundamental Law no other legislation but the Fundamental Law is entitled to arrange. It is considered an important guarantee that not even in the qualified period can the implementation of the Fundamental Law be suspended and the functioning of the Constitutional Court may not be restricted. The exercise of fundamental rights may be restricted or suspended to a different extent then stated in the legislation applying to a time of peace, some basic rights (human dignity and the dignity of human life) on the other hand remain untouchable. ${ }^{15}$

The special legal order is covered by a separate section of the Fundamental Law, in Articles 48-54. The detailed measures of regulation applied in special legal order are laid down in a series of Cardinal Law, thus Act CXIII of 2011 on national defence and Hungarian Defence Force, and about the regulations to be introduced in special legal order, furthermore the relating Act CXXVIII of 2011 about disaster management and about amendments of disaster management. As a first step, five types of special legal order were determined: state of emergency in the case of international conflict, emergency of domestic origin, state of emergency declared in the case of national unrest and civil war,

13 Simicskó István: A terrorizmus elleni védelem fokozása a különleges jogrendi kategóriák bővítésével, Hadtudomány 2016/3-4, 113. (The enhancement of defence against terrorism with the enlargement of legal categories).

14 Csink Lóránt: „Mikor legyen a jogrend különleges?” lustiumAequumSalutare 2017/4, 7-16. („When should the legal order be special?").

15 Draft law no. T/167 with reasoning attached - General reasoning to the Fundamental Law of Hungary, to article 47-53. 
in the case of military threat previous defence situation prior to the declaration of the state of emergency, the case of unexpected external attack, emergency condition to be declared if the security of human life and possessions is endangered by natural disaster of by industrial catastrophe.

Since the second millennium global politics and global threat has gone through immense change. In March 2011 the Syrian civil war started, leading to the fall of the country's administration, as a result the territory of the country has been divided up into several territorial powers governed by political fractions supported by external interests. On the ruins of the demolished country an entity of terrorism, the Islamic State has emerged. Climatic change - which is also dependent on global features and processes generated serious and at present not fully known changes. Above all in the countries of Africa and the Near East whose inhabitants, due to overpopulation and hunger and motivated possibly by external political or economic circles made the decision to set off and migrate towards Europe, seeking to find honest work or simply wishing to partake in the financial security offered by the excellent supply systems of European states. The present author has already warned (in 2008) that migration proves to be one of the most serious challenges of our age. It may easily occur that mass migration reaches a measure over the critical mass level and this can result in a situation of qualified period. ${ }^{16}$ The migration crisis of 2015 experienced by the whole world but suffered above all by Europe must be considered as a direct consequence of these factors. Analysing the data of EUROPOL and FRONTEX Róbert Bartkó came to the conclusion that the masses of migrants - without checking their backgrounds and intentions -, predominantly young men without lacking the intention to co-operate with the European authorities, ${ }^{17}$ in other words illegal migration, seems to be a very useful tool for terrorist groups and organizations. ${ }^{18}$

The sixth amendment Of the Fundamental Law of Hungary with effect as 1 July 2016 introduced a new form of qualified period, called emergency condition brought upon by terrorism. This new form of qualified period is to be applied in the immediate danger of terrorist attack or in the case of actual terrorist attack. The justification of the modification records that the environment of security in the trans-atlantic region, in Europe and in Hungary within Europe has gone through fundamental change and "all over the world new types of security challenges have appeared where - bearing in mind the requirement of necessity-proportionality - the previous responses by the introduction of qualified period in the situation of classical international military threats cannot be addressed." Furthermore, it is recorded that "the new types of security challenges are not at all possible to fit in" the already existing framework of special legal orders. ${ }^{19}$

16 Simicskó István: Az országvédelem és országmozgósítás szervezeti, hatásköri, irányítási rendszere minősített időszakokban, Doktori értekezés, ZMNE-HTK 2008, 24. o.

17 According to the data of EUROSTAT (source: Immigration by age and sex - Products Datasets - Eurostat (europa.eu)).

18 Bartkó Róbert: Az illegális migráció és a terrorizmus kapcsolata az EUROPOL és a FRONTEX jelentéseire tekintettel. (The relation of illegal migration and terrorism based on reports by EUROPOL and FRONTEX).

19 Draft law no. T/10416 - about the 6th amendment of the Fundamental Law of Hungary. 


\section{The new directions of the development in the legislation of the special legal order}

After the regime change neither the modification of the "party-state" constitution nor the Fundamental Law has brought about essential changes in the legislation of the Hungarian system of special legal order. One of the main causes of this phenomenon is the fact that in the last thirty years of Hungary's history not one event occurred which would have justified the utilization of the provisions of special legal order. In the case of emergency state the partial introduction of emergency condition of the 2013 flood applying to the endangered region of Hungary has set an example. ${ }^{20}$

The appearance of the COVID 19 pandemic and its predictable social and economic consequences must urge each responsible statesman and politician to consider the effectiveness of security strategies, the regulations of special legal order among them, in this changed environment. Recognizing the consequences of the first wave of the pandemic as well as acknowledging the necessity of the fast and effective protection policy the Hungarian government declared emergency condition applying to the whole territory of Hungary, first on 11 March $2020^{21}$ and in the second wave of the pandemic on 3 November 2020, ${ }^{22}$ implementing the powers stated in the Fundamental Law (53. article, 1. paragraph) and taking into consideration the modifications of the laws on disaster protection (Act CXXVIII of 2011, paragraph 51/A) stating: "in order to overcome the consequences of the SARS-CoV-2 Coronavirus pandemic (Coronavirus pandemic in the following) that endangers the security of human lives and possessions and causes mass illnesses and in order to protect the health and lives of Hungarian citizens an emergency condition is declared applying to the whole territory of Hungary."

For the sake of completeness, Pál Kádár summed up the necessity appearing within academic circles to prepare a revision of the cases of special legal orders, ${ }^{23}$ arguing that the legislation currently in force seems complicated and there is a risk that an overregulated legislation loses its special character. The review of the entitlements emerging in the times of special legal order has also become necessary, together with the exact definition of the addressees of these entitlements and the appointment of those persons or authorities who may be taken as substitutes of the addressees. In an analysis published in 2018 and referring to the above mentioned reasons Áron Ösze highlighted three such sets of cases: case of emergency, state of emergency, and emergency condition. ${ }^{24}$

The experience of the introduction of special legal order in 2020, with the adjoining measures and fast implementation of disease (in this case pandemic) control and economy

20 177/2013. (VI. 4.). Government regulation on the declaration of emergency condition and the measures required.

21 Government Decree 40/2020 (11 March) on the declaration of state of danger.

22 Government Decree 478/2020. (3. November). on the declaration of state of danger.

23 Kádár Pál: A különleges jogrendi szabályozás megújítása és a Magyar Katonai Jogi és Hadijogi Társaság، Katonai Jogi és Hadijogi Szemle 2020/4, 7-34. (The revision of the regulations of special legal order and the Society of Hungarian Military Law and War Legislation).

24 Ösze Áron: Analízis a magyar különleges jogrendi szabályozás hatékonyságáról, Diskurzus, 8/2, 33-44. (Analysis of the effectiveness of the Hungarian legislation of special legal order). 
protection, together with the new types of security challenges like the spread of hybrid warfare inspired the Hungarian legislating body to revise and modernize the regulations of special legal order. The legal rules applying to the special legal order have been placed on renewed basis by the Fundamental Law of Hungary, with effect from 1 July 2023. The purpose of this revision was to provide a flexible yet more effective solution to manage severe crisis situations, a solution equipped with the relevant guarantees of rule of law. The future undoubtedly has unknown global challenges for the world, for Europe, and for Hungary. The Hungarian legislator could decide whether to maintain the present more specific regulations, i.e. keeping the applicability of special legal order cases distinguished by the different endangered groups of society, or to make a shift towards more general ruling, acknowledging the fact that the legal environment can only ensue the wide sceptre of possible dangerous situations and distress, due to the natural phenomenon of distress appearing well before it has been recognized, therefore the need to prepare ourselves against it which precipitates the conformity of the legal environment also emerges later than distress itself. András Jakab and Szabolcs Till notes that the more complicated the spectre of causes is, the more legal cases are incorporated in the term special legal order, the more possibly one will confront the waywardness originating from complicated regulation. The authors conclude that a revision of partial categories is made inevitable by the need for regulating of the new challenges of external environment. ${ }^{25}$ According to Lóránt Csink there is no exact definition for the reason of special legal order, as the circle, the frequency and social significance of the phenomena which would provide the reasons are changing continuously. He argues that in the course of legislation the diverse nature of the previously mentioned phenomena are to be seriously considered. In the analysis of the stability of the regulation the author remarked that only the non-detailed regulation can remain stable. He came to the conclusion that only short authorization is needed for the introduction of the special legal order and for the appointment of the competent body exercising these powers and measures. This competent body is to be given the framework of possible measures, at the same time it is vital to deploy an effective political and independent legal control mechanism. ${ }^{26}$ One may add however that in the security environment of today both the strong differentiation may cause serious difficulties concerning preparation period and the question of rapid decisions in complex situations. Parliament chose the more general albeit more simple and in the long run more stable solution when in the Fundamental Law of Hungary it reduced the number of the previous 6 cases of special legal order to three categories more transparent and carefully adjusted to the modern challenges: state of war, state of emergency and emergency condition.

With the new legislation the Fundamental Law makes it quite clear that the state of war is a state of special legal order that primarily requires military response, the state of emergency serves to address conflicts within the state borders, the emergency condition is declared to clear disaster situations. The Parliament is entitled to declare the state of war and the state of emergency. The emergency condition is to be declared

25 Jakab András - Till Szabolcs: X. Alkotmányvédelem - Különleges jogrend, JAK-PPKE, 1033-1072. (X. Constitutional Defence - Special legal order).

26 Csink Lóránt: „Mikor legyen a jogrend különleges?” lustumAequumSalutare 2017/4, 7-16. („When should the legal order be special?"). 
by the government for 30 days but only the Parliament is entitled to give authorization for the further extension of the emergency the republic discontinues. As a critical remark concerning the Council of National Defence Szabolcs Till emphasized that the Council itself caused an uncertainty in the operation, as it was supposed to handle the most serious danger in state functioning, but as lacked any authority in the period of peace it had no opportunity to acquire relevant experience in the operation practice. ${ }^{27}$ In the course of the amendment the novum is not presented by the fact that it is the government who lays down the contents of the general binding rules of conduct for the entire duration of special legal order, as this applies to normal circumstances as well, rather that the government can act in the interest of the more effective action without the Parliament. According to the argument of the legislator: "following the declaration of special legal order in order to undertake rapid and operative proceedings the ensuring of responsible ruling - both in political and in legal sense - is necessary. In the Hungarian constitutional system the Government seems to be suitable for this role. "28 Furthermore, as a measure of guarantee and a novum compared to the previous measures the ninth amendment of the Fundamental Law states that "the Government is obliged to take all the necessary steps to ensure the continuous work of the Parliament". ${ }^{29}$ In sum, apart from the president of the republic and the Constitutional Court - whose uninterrupted practice has already been ensured by the Fundamental Law - the Parliament performs constant monitoring function towards the government which assumes extraordinary rule - and obviously bears extraordinary responsibility. The legal basis for this practice has been provided not only by the rules and regulations to be applied in the course of special legal order but also the rules and regulations of normal legal order that apply in the course of special legal order. The details of regulations must be settled in a cardinal law.

The following are to be considered cardinal laws: the Act CXIII of 2011 on national defence and the Hungarian Defence Force, and on the measures implemented in the course of special legal order, the Act CXXVIII of 2011 on disaster management in relation to the emergency condition and the amendments of certain laws attached, giving details of the guarantee regulations concerning empowerment in special legal order. Amidst this circle these legislations define those exceptional measures which the government, the addressee of exceptional rule in special legal order is entitled to introduce. The local requirements, demands and tasks of the implementation of these regulations are defined by the local authorities of defence administration within their local competence.

\section{Summary}

Perhaps the only safeguarding mechanism of the rule of law appears to be the application of the cases of special legal order. The rules set out in the Fundamental Law and in cardinal laws provides the normal periodic system of checks and balances, such as the committees

27 Till Szabolcs: „Különleges jogrend” in Jakab András - Fekete Balázs (eds.): Internetes Jogtudományi Enciklopedia, 2019. [37] („Online Encyclopedia of Legal Science”).

28 Draft law no. T/13647. with reasoning attached - the 9th amendment to the Fundamental Law of Hungary, to the 11. paragraph.

29 The ninth amendment of the Fundamental Law (22 December 2022, paragraph 52, subparagraph (3). 
of Parliament, or the role of the president of the republic in accordance with certain legal acts of the government. The sovereignty and the functioning of the state and the removal of sources of danger threatening the security of life and possessions of the country's citizens in certain periods of special legal order is ensured by the right of deduction outside the central order of power appointed by Parliament.

Most recently, the new types of security challenges, i. e. global terrorism, mass illegal migration, the appearance of hybrid warfare and its increasing sophistication, the pandemic, as well as natural disasters caused by climatic change has been forcing us to maintain the review and the constant update of the regulations of special legal order. This can indeed be defined as a new level of the constitutional development, as the core of the rules in force at present has developed as a result of a long process during the last century, enrooted in earlier sources of legal history, finally took coherent form in 1989. This review of the special legal order has however been born from the fear of the return of the partystate, therefore it has become - at least in the opinion of the modern spectator - overregulated employing unjustified and excessively cumbersome practical methods. In 2011 the Fundamental Law was implementing this material as its foundation, as the appearance and the measure of the new security challenges did not require a different approach. Subsequently, the legislator had to give an adequate response which has resulted in the codification of the case of terror emergency.

On the basis of the special legal order of emergency condition introduced because of the Coronavirus-pandemic and influenced by security issues gathered recently the Parliament, with the ninth amendment of the Fundamental Laws suspended the majority of applicable cases thus accomplishing a comprehensive reform of the whole system satisfying at the same time the need for simplification witnessed in legal scientific writings. Hungarian legislation has chosen a flexible, yet stable solution to meet the familiar but also the so far unfamiliar challenges, corresponding to the requirements adequately noted by Szabolcs Till: "the constitutional system is ought to keep its operability in a hybrid environment." 30

We sincerely hope that the employment of special legal order and its regulations will not appear as precedent in the future. However, keeping in mind the principle of "hope for the best, but prepare for the worst" it is the legislature's task to estimate the new challenges and to constantly review the framework of rules. As the partial rules are at present being appointed by the cardinal laws which makes the legislation non-transparent and fractured (in accordance with Pál Kádár's opinion) ${ }^{31}$ further simplification would be the right direction. If a security management codification containing the relevant measures in a unified framework - covering the duties and authority of the sectors concerned as well as the framework of central co-ordination of national defence and civil security and national defence security management - were accomplished in that case a new foundation would be created for the sectors and organizations concerned.

30 Till Szabolcs: A különleges jogrendi kategóriarendszer egyszerüsítésének jövőbeli esélyei, lustumAequumSalutare 2017/4, 55-75. (Future opportunities of the simplification of the category system of special legal order).

31 Kádár Pál: A különleges jogrendi szabályozás megújitása és a Magyar Katonai Jogi és Hadijogi Társaság, Katonai Jogi és Hadijogi Szemle 2020/4, 7-34. (The revision of the regulations of special legal order and the Society of Hungarian Military Law and War Legislation). 


\section{References}

The Fundamental Law of Hungary.

Draft law no. T/2627 with reasoning attached - on the Fundamental Law of Hungary.

Draft law no. T/10416 with reasoning attached - the 6th amendment to the Fundamental Law of Hungary.

Draft law no. T/13647. with reasoning attached - the 9th amendment to the Fundamental Law of Hungary, to the 11. paragraph.

The Act LXIII. of 1912, paragraph 1, on the extraordinary measures in the event of war.

The Act L. of 1914, the first amendment to the the LXVIII. Law Act of 1912 on the provision of war services.

The Act XII. of 1935, paragraphs 1 and 2, on air defence system.

The Act XX. of 1938 on military defence, on the development of economy, on welfare developments and their financial background.

The Act II. of 1939 on national defence.

The Act XX. of 1949 on the Conbstitution of the Hungarian Republic.

The Act IV. of 1960, on national defence.

The Act XXXI. of the amendment of the Constitution.

The Act CVII. of 1993, on the amendment of the Constitution.

The Act XXXIV. of 1994, on the police force.

The Act CIV. of 2004, the amendment of Law Act of 1949 on the Constitution of the Hungarian Republic.

The Act CXII. of 2011 on national defence and on the Hungarian Defence Force, and on the rules to be introduced in special legal order.

The Act CXXVIII. of 2011 on disaster management and on the amendments of laws attached. 
Government Decree 177/2013. (4 June). Government regulation on the declaration of state of danger and the measures required.

Government Decree 40/2020 (11 March) on the declaration of state of danger.

Government Decree 478/2020. (3 November) on the declaration of state of danger.

The ninth amendment of the Fundamental Law (22 December 2022, paragraph 52, subparagraph (3).

BARTKÓ, Róbert: Az illegális migráció és a terrorizmus kapcsolata az EUROPOL és a FRONTEX jelentéseire tekintettel. (The relation of illegal migration and terrorism based on reports by EUROPOL and FRONTEX).

CSINK, Lóránt: „Mikor legyen a jogrend különleges?" in: lustumAequumSalutare, 2017, 4, 7-16. („When should the legal order be special?”).

FARKAS, Ádám, Az állam fegyveres védelmi rendszerének kérdései a kortárs fenyegetések tükrében, in: Katonai Jogi és Hadijogi Szemle, 2015, 1, 140-142. (The questions of the state armed defence system in the in the reflection of contemporary threats).

FARKAS, Ádám - KÁDÁR, Pál: A különleges jogrendi szabályozás fejlődése és katonai védelmi vonatkozása. In: FARKAS Ádám - KÁDÁR Pál (szerk.): Magyarország katonai védelmének közjogi alapjai. 2016. Zrínyi Kiadó, Budapest 303-307. (Development of special legal order and its aspects of defense).

JAKAB, András - Till Szabolcs: X. Alkotmányvédelem - Különleges jogrend, JAK - PPKE, 1033-1072.

JAKAB, András (szerk.): Az Alkotmány kommentárja I. Századvég Kiadó, Budapest, 2009. 231-666. (Commentary of the Constitution vol. I.).

JAKAB, András: Az új Alaptörvény keletkezése és gyakorlati következményei. Budapest, HVG-Orac, 2011. (The emergence and practical consequences of the new Fundamental Law).

KÁDÁR, Pál: A különleges jogrendi szabályozás megújítása és a Magyar Katonai Jogi és Hadijogi Társaság, in: Katonai Jogi és Hadijogi Szemle, 2020, 4, 7-34. (The revision of the regulations of special legal order and the Society of Hungarian Military Law and War Legislation).

LAKATOS, László: A különleges jogrend és a honvédelem szabályozása, MTA Law WorkingPapers, 2014, 49. (Special legal order and the regulation of national defence). 
NÉMETH, Hajnalka: Spanyolnátha. A világméretű rejtélyes járványról egy kicsit másképp, in: Better Responsibility Initiative, 2019-2020. (Spanish Flu. Reflections on the Mysterious Pandemia from a Different Viewpoint).

ÖSZE, Áron: Analízis a magyar különleges jogrendi szabályozás hatékonyságáról, Diskurzus - The Academic Journal of the Lajos Batthyany College of the Ferenc Deák Faculty of Law at the University of István Széchenyi 8, 2, 33-44. (Analysis of the effectiveness of the Hungarian legislation of special legal order).

SIMICSKÓ, István: A terrorizmus elleni védelem fokozása a különleges jogrendi kategóriák bővitésével, in: Hadtudomány, 2016, 3-4. 113. (The enhancement of defence against terrorism with increasing the categories of special legal order).

SIMICSKÓ, István: A terrorizmus elleni védelem fokozása a különleges jogrendi kategóriák bővítésével, in: Hadtudomány, 2016, 3-4, 113. (The enhancement of defence against terrorism with the enlargement of legal categories).

SIMICSKÓ, István: Az országvédelem és országmozgósítás szervezeti, hatásköri, irányítási rendszere minősített időszakokban, Doktori értekezés, ZMNE-HTK 2008, 24. o.

SIMICSKÓ, István: A hibrid hadviselés előzményei és aktualitásai, Hadtudomány, 2017, 3-4. (The precedents of hybrid warfare and its actualities).

TILL, Szabolcs: A különleges jogrendi kategóriarendszer egyszerúsítésének jövőbeli esélyei, in: lustumAequumSalutare, 2017, 4, 55-75. (Future opportunities of the simplification of the category system of special legal order).

TILL, Szabolcs: „Különleges jogrend” in: Internetes Jogtudományi Enciklopedia, Jakab András - Fekete Balázs (eds.), 2019. [37] („Online Encyclopedia of Legal Science”).

\section{Author}

Dr. István Simicskó

Professor Titular, University of Public Service

Üllői út 82.

1083 Budapest, Hungary

simicsko.istvan@fidesz.hu 
